\title{
Bioética: comunicación científica y realidad social
}

\author{
Juan María Cuevas Silva* \\ Giovane Mendieta Izquierdo**
}

DoI: http://dx.doi.org/10.18359/rlbi.2730

\begin{abstract}
Cómo citar:
Cuevas Silva, J. M. y Mendieta Izquierdo, G. (2016). Bioética: comunicación científica y realidad social. Revista Latinoamericana de Bioética, 17(1), 5-7. DoI: http://dx.doi.org/10.18359/rlbi.2730
\end{abstract}

¿Cuál es el sentido de publicar revistas indexadas? Este interrogante se ha hecho más contundente y crítico en Colombia, teniendo en cuenta la política establecida por Colciencias, ${ }^{1}$ por medio de Publindex ${ }^{2}$ organismo encargado de establecer los criterios y políticas del sistema nacional de indexación de revistas científicas, desde donde se centra la preocupación por la visibilidad y el impacto de las publicaciones, dando prioridad a los índices de citación que han recibido las revistas, así como a los académicos e investigadores que intervienen en el proceso editorial, bien sea como autores, evaluadores, o miembros de los comités editorial o científico. Las "nuevas" exigencias para que una revista científica sea indexada en Colombia son una muestra más del aletargamiento de los procesos editoriales científicos en nuestra nación, llevados a cabo por más de 20 años. Publicar hoy trae consigo una serie de exigencias que van desde lo artesanal hasta lo más tecnológico, pero en Colombia nos hemos quedado en lo artesanal, en la era de la imprenta de Gütemberg. A pesar de la prolífica producción literaria científica, existente en nuestro país en los últimos 20 años, se nos presentan tres problemas: uno referente a la calidad científica de lo publicado; dos, el aporte a la realidad social, y tres, el sentido ético de la publicación científica.

\footnotetext{
* Magíster en Educación y doctorante en Procesos Políticos y Sociales en América Latina. Profesor asistente, Facultad de Educación y Humanidades, Universidad Militar Nueva Granada. Editor de la Revista Latinoamericana de Bioética. Correo electrónico: juan.cuevass@unimilitar.edu.co; revista.bioetica@unimilitar.edu.co. ORCID: http://orcid.org/0000-0002-1680-6223, Bogotá, Colombia.

** Magíster en Educación y doctor en Ciencias de la Salud Pública. Profesor asistente, Facultad de Educación y Humanidades, Universidad Militar Nueva Granada; coeditor de la Revista Latinoamericana de Bioética. Correo electrónico: giovane.mendieta@unimilitar.edu.co. ORCID: http:// orcid.org/0000-0002-5085-3242, Bogotá, Colombia.

1 "Entidad pública que lidera, orienta y coordina la política nacional de ciencia, tecnología e innovación, y el Sistema Nacional de Ciencia, Tecnología e Innovación para generar e integrar el conocimiento al desarrollo social, económico, cultural y territorial del país" (tomado de http:// www.colciencias.gov.co/colciencias/sobre_colciencias/mision-vision.

2 Es el Índice Bibliográfico Nacional de Colombia, que indexa y homologa las revistas científicas.
} 
¿Qué es la calidad científica? ¿Quién determina que un artículo es científico? ¿Qué es la cultura de la calidad científica? Hacer este tipo de preguntas, obvias para algunos sectores académicos, exige un análisis de lo que significa la comunicación científica, aspecto que en el contexto colombiano muy poco se ha analizado y debatido, ya que la preocupación ha estado centrada en publicar sin importar qué, lo importante es publicar. Este desconocimiento de la calidad científica, reemplazada en el contexto colombiano — en algunos autores_ por el afán de "publicar", no permite hacer un acercamiento al valor de publicar con calidad científica; es decir, que se publica aquello que aporta al conocimiento, que además, por su naturaleza, ofrece elementos para la transformación o cambios sociales. En otras palabras, el afán de publicar en Colombia nos llevó a considerar que todo era científico, pero al revisar su pertinencia social pierde su valor. Resulta curioso que al analizar la historia de las publicaciones científicas en Colombia, se ha podido observar que estas últimas se han caracterizado por desconocer el sentido de la comunicación científica; es decir, se ha olvidado que se requiere un emisor, receptor, mensaje, canal, código, contexto. Más curioso aun, cuando con estas publicaciones el Estado y las universidades públicas han reconocido por ley puntajes salariales; pero al evaluar esas publicaciones, el trasegar científico del país va cada vez más hacia atrás. El mercado de los rankings nos está sometiendo a las falacias de las publicaciones científicas: la visibilidad y el impacto, características propias de una sociedad salvaje del mercado del conocimiento, en la que están emergiendo y, al mismo tiempo, se están fortaleciendo imperios de indización, a costa de una ciencia desconectada de la realidad y sus contextos.

Esto lleva a abordar el segundo problema: el aporte a la realidad social. En otros tiempos la calidad científica, supóngase en la época de Galileo o del Sabio Caldas, tenía como sentido aportar a la calidad de vida de los seres humanos; hoy debería hablarse del sentido bioético, es decir, que la calidad científica aporte a la vida en toda su complejidad. Pero desafortunadamente la calidad científica va de espalda a la realidad del país y de la vida. Somos del sur y queremos hacer publicidad científica como los del norte; hablamos, leemos y medio nos comunicamos en castellano, y ya queremos que nos lean en inglés o cualquier otra lengua implantada por la "fracasada globalización"; 3 investigamos y hacemos ciencia desde nuestro contexto, pero no nos leemos entre nosotros, pues consideramos que es mejor lo extranjero que lo nuestro, lo regional. En algunas áreas de conocimiento, como lo son las ciencias sociales y las humanidades, se publican más artículos de reflexión que de investigación, lo que genera una dualidad de mundos: el intelectual y el real, al estilo del pensamiento platónico. En otras palabras, creemos que nos comunicamos

Concepción y conceptualización abordada por Joseph E.Stiglitz, Zigmund Bauman, Klaus Bodemer, Peter Sloterdijk, Samir Amin, entre otros. 
científicamente, pero nos quedamos como meros emisores sin receptores; es decir, se logró publicar, pero no comunicar, no toda publicación científica es una comunicación científica. En este sentido, más que una política para indexar, se requiere una "cultura de comunicar científicamente", ya que con una política desconectada de la realidad de la ciencia del país y de la producción de sus investigadores lo único que se logra es agravar el sentido de la comunicación científica, y esto limita su valor a un impacto y visibilidad en los emporios de indización mundial. Sería interesante que nos leyeran en el mundo, que nos citaran, pero más interesante sería que realmente nuestros códigos de comunicación científica tengan acogida por su aporte significativo al conocimiento, la ciencia y la vida en general, es decir, por su pertinencia dentro del contexto nacional y, por ende, mundial, pero no podemos apostarle a ser impactantes en el mundo sin serlo en nuestra nación.

El sentido ético de la comunicación científica es un tercer problema, entre otros tantos que se podrían enumerar. La visibilidad y el impacto, junto a la calidad científica y la pertinencia sociocientífica, pierden todo su sentido si se desconocen, o no se realizan con base en los principios éticos de la comunicación científica. El país del "Sagrado Corazón", ${ }^{4}$ católico por tradición más no por Constitución Política, preocupado por la formación en valores éticos y conciencia moral, no ha podido ser coherente entre su discurso y su acción, ante lo cual no es ajena la comunicación científica. Estuvimos dos décadas consagrados bajo el principio "publícame que yo te publico"; ahora la invitación de la política es "cítame que yo te cito". Las prácticas perversas en la publicación científica se pueden evitar siempre y cuando el emisor del mensaje científico tenga conciencia de qué está comunicando, para lo cual debe tener presentes unos principios, que no se pueden limitar a la originalidad o al plagio, al manejo adecuado de datos e información, sino que también deben abarcar principios referentes al sentido social de la comunicación científica desde el espíritu científico, que al fin y al cabo es lo que hace que una publicación o revista sea científica.

La comunicación científica y la realidad sociocientífica, tienen sentido cuando son acogidas en las comunidades académicas de conocimiento y por medio de ellas se llega a los cambios y a la transformación social; en esto se resume el sentido de una revista indexada, de tal forma que su visibilidad e impacto se darán por naturaleza propia. Una política de indexación nacional no se puede limitar a su afán de responder a estándares internacionales que, entre otras cosas, desde antaño los han venido trabajando en otros países. Glocalizacemos nuestra comunicación científica, sin caer en las redes del fracaso de la globalización y el mito de la indización.

$4 \quad$ Advocación propia de Colombia desde inicios del siglo xx, usado popularmente para referirnos al país. 